Article

\title{
Electrolytic Manganese Dioxide Coatings on High Aspect Ratio Micro-Pillar Arrays for 3D Thin Film Lithium Ion Batteries
}

\author{
Yafa Zargouni ${ }^{1,2,3,4, *}$, Stella Deheryan ${ }^{2,4}$, Alex Radisic ${ }^{2}$, Khaled Alouani ${ }^{3}$ and \\ Philippe M. Vereecken ${ }^{2,4}$ \\ 1 KACST-Intel Consortium Centre of Excellence in Nano-Manufacturing and Applications (CENA), \\ Riyadh 11442, Saudi Arabia \\ 2 Imec, Kapeldreef 75, B-3001 Leuven, Belgium; stella.deheryan@jsrmicro.be (S.D.); \\ alex.radisic@imec.be (A.R.); philippe.vereecken@imec.be (P.M.V.) \\ 3 Laboratoire de Chimie Analytique et D'électrochimie, Faculté des Sciences de Tunis, Université de \\ Tunis-El-Manar, Tunis 2092, Tunisie; khaled.alouani@gmail.com \\ 4 KU Leuven, Centre for Surface Chemistry and Catalysis, Faculty of Bioscience Engineering, Kasteelpark \\ Arenberg 23 bus 2461, B-3001 Leuven, Belgium \\ * Correspondence: yafa.zargouni@fst.utm.tn; Tel.: +20-102-265-9001
}

Academic Editor: Guanying Chen

Received: 5 April 2017; Accepted: 22 May 2017; Published: 27 May 2017

\begin{abstract}
In this work, we present the electrochemical deposition of manganese dioxide $\left(\mathrm{MnO}_{2}\right)$ thin films on carbon-coated TiN/Si micro-pillars. The carbon buffer layer, grown by plasma enhanced chemical vapor deposition (PECVD), is used as a protective coating for the underlying TiN current collector from oxidation, during the film deposition, while improving the electrical conductivity of the stack. A conformal electrolytic $\mathrm{MnO}_{2}$ (EMD) coating is successfully achieved on high aspect ratio $\mathrm{C} / \mathrm{TiN} / \mathrm{Si}$ pillar arrays by tailoring the deposition process. Lithiation/Delithiation cycling tests have been performed. Reversible insertion and extraction of $\mathrm{Li}^{+}$through EMD structure are observed. The fabricated stack is thus considered as a good candidate not only for 3D micorbatteries but also for other energy storage applications.
\end{abstract}

Keywords: electrodeposition; EMD; thin film; carbon; 3D current collector; microbatteries

\section{Introduction}

In the last few years, there has been a growing interest in the improvement of power supply sources to satisfy the increasing demands for energy [1]. Among the conventional energy storage systems, lithium-ion batteries (LIBs) are considered state-of-the-art technology for application in smart electronic devices due to their high energy density [2,3]. In this regard, considerable attention has been paid to the development of lithium ion microbatteries in both thick and thin film forms [4]. However, the planar form of the current thin-film batteries provides only limited capacity $\left(<1 \mathrm{mAh} / \mathrm{cm}^{2}\right)$ which restricts their use to the low power applications. In spite of the achievements in the optimization of thin film microbatteries designs, their limitations motivate researchers to find new alternatives [4]. Therefore, new approaches to electrode design have been identified to achieve fast battery charging combined with high energy density. In this respect, micro-fabrication and/or nano-structuring of three-dimensional (3D) current collectors with high aspect ratios provide enlarged surface area [5]. This results in the quantitative increase of the deposited active material while keeping the thin film assembly to provide short ion diffusion paths and good electron harvesting pathways (Scheme 1) [6-10]. 


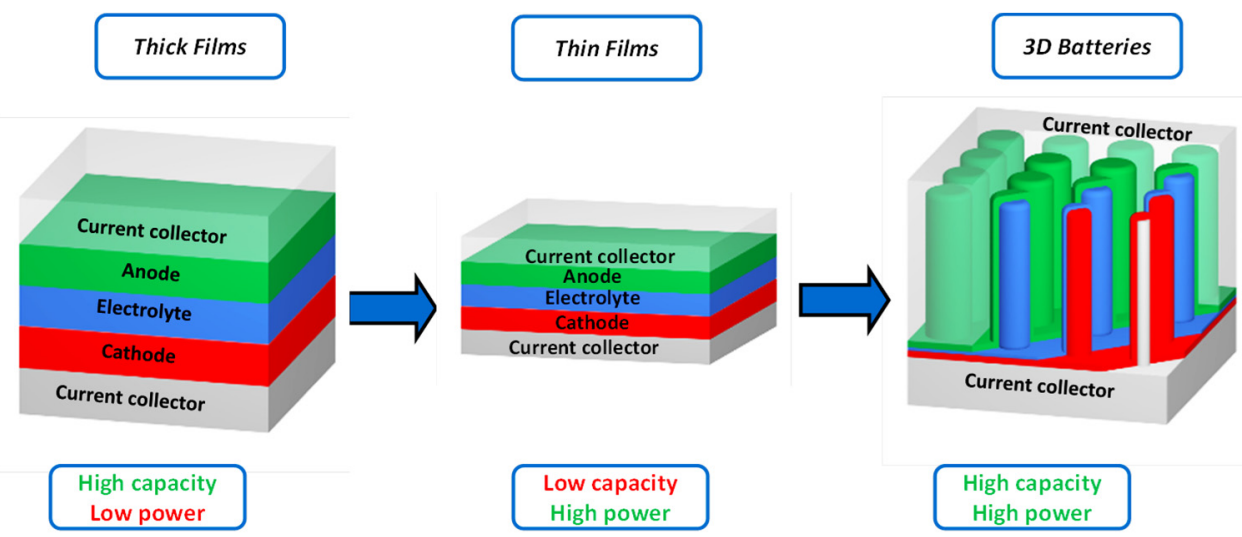

Scheme 1. Illustration showing the evolution from planar thin-film batteries with 1 to $2 \mu \mathrm{m}$ thick electrode films to 3D thin-film batteries with sub-micrometre thin films.

Several methods for 3D electrodes manufacturing have been reported in the literature $[7-9,11,12]$. Silicon ( $\mathrm{Si}$ ) is widely used as processing material for electronic devices integration $[13,14]$. Hence, Si patterning electrochemically or via deep reactive ion etching (DRIE) techniques has led to high aspect ratio structures, for microbatteries and micro-electro-mechanical-systems (MEMS) applications [15-17]. Usually, Si microstructured substrates require a barrier diffusion layer of titanium nitride (TiN) or tantalum nitride $(\mathrm{TaN})$ to prevent $\mathrm{Li}$ ions penetration into Si. Such thin film also ensures the electrical contact and is considered as current collectors owing to their sufficient conductivity [18-20].

Three-dimensional electrode architectures have been proposed so far in numerous research works $[15,21,22]$. For example, micro-channels through $\mathrm{Si}$ as well as deep trench architectures have been reported $[17,23]$. Nanowire arrays and nanorods have been also detailed showing an improvement in electrode performance due to the current collector geometries as well as the deposited active materials like $\mathrm{Cu}_{2} \mathrm{Sb}, \mathrm{Fe}_{2} \mathrm{O}_{3}$ and $\mathrm{TiO}_{2}$ [7,24-27]. Such materials can be prepared by a variety of techniques such as electrochemical deposition (ECD) [12,28], atomic layer deposition (ALD) [29,30], chemical vapor deposition (CVD) [31], and sol-gel deposition [9]. For 3D current collectors, the deposition of a conformal coating is challenging. To date, ALD is considered the common technique to make a conformal coating on high aspect ratio structures [32]. However, it needs expensive precursors and the deposition time is relatively long [31,33]. In contrast, ECD is a cost-effective method that allows a conformal deposition of the active material over 3D complicated structures [8].

Since the 1990s, manganese dioxide $\left(\mathrm{MnO}_{2}\right)$ has been considered promising material for batteries [34,35] for its low cost, non-toxicity, natural abundance of $\mathrm{Mn}$ and the ease of manufacturing [36-38]. The $\mathrm{Li} / \mathrm{MnO}_{2}$ battery system is known as a primary cell with an operating voltage of $3 \mathrm{~V}$ and a $\mathrm{MnO}_{2}$ electrode capacity up to $250 \mathrm{mAh} / \mathrm{g}$ [39-41].They are also widely utilized in capacitors [42], hybrid(asymmetric) capacitors [43], supercapacitors [44] and electrocatalysis applications [45,46]. Among the different polymorphs of this metal oxide, $\gamma-\mathrm{MnO}_{2}$ is the most electrochemically active form [47]. It is mainly produced by ECD and called electrolytic manganese dioxide (EMD) [40]. $\gamma-\mathrm{MnO}_{2}$ is described as an intergrowth between Pyrolusite and ramsdellite-forms of $\mathrm{MnO}_{2}$ [27]. The as-prepared EMD contains water in its film structure [48]. In order to enable reversibility and avoid lithium hydroxide formation upon Li-ion intercalation tests, removal of water from EMD thin films is necessary. Therefore, post deposition annealing between 250 and $400{ }^{\circ} \mathrm{C}$ is essential [49]. This heat treatment leads to an enhanced lithium diffusivity in the electrode accompanied with improved crystallization and grain growth [48-50]. Previous studies reported the deposition of EMD on Si substrates coated with TiN and Pt seed layers as current collectors. It was revealed that TiN gets oxidized during EMD formation and the $\mathrm{TiON}_{x}$ passivating layer prevents much more growth of the deposited film $[10,51,52]$. In the case of Pt current collector, EMD films delaminated when reaching a thickness more than $200 \mathrm{~nm}$ because of the poor adhesion between Pt and EMD [51]. Recently, we 
demonstrated that a carbon coating, grown by plasma enhanced chemical vapor deposition (PECVD), on TiN protects it from oxidation and enables the deposition of up to $500 \mathrm{~nm}$ EMD film. The carbon buffer layer acts as a protective coating, enhances the adhesion between TiN and EMD and improves the electrical conductivity of the stack. Thus far, only results for planar C/TiN/Si substrates were reported [52].

In this paper, we study the deposition of EMD coatings on high aspect ratio (60:2) TiN/Si pillars. Prior to film deposition, the 3D substrate was coated with the PECVD carbon layer, (Scheme 2). The use of carbon coating, as well as the morphology of EMD on improving the reversible Li-ion intercalation kinetics for the assembled electrode, will be examined $[52,53]$. The influence of the bath temperature, from which the film was deposited, as well as the impact of film thickness, are also investigated.

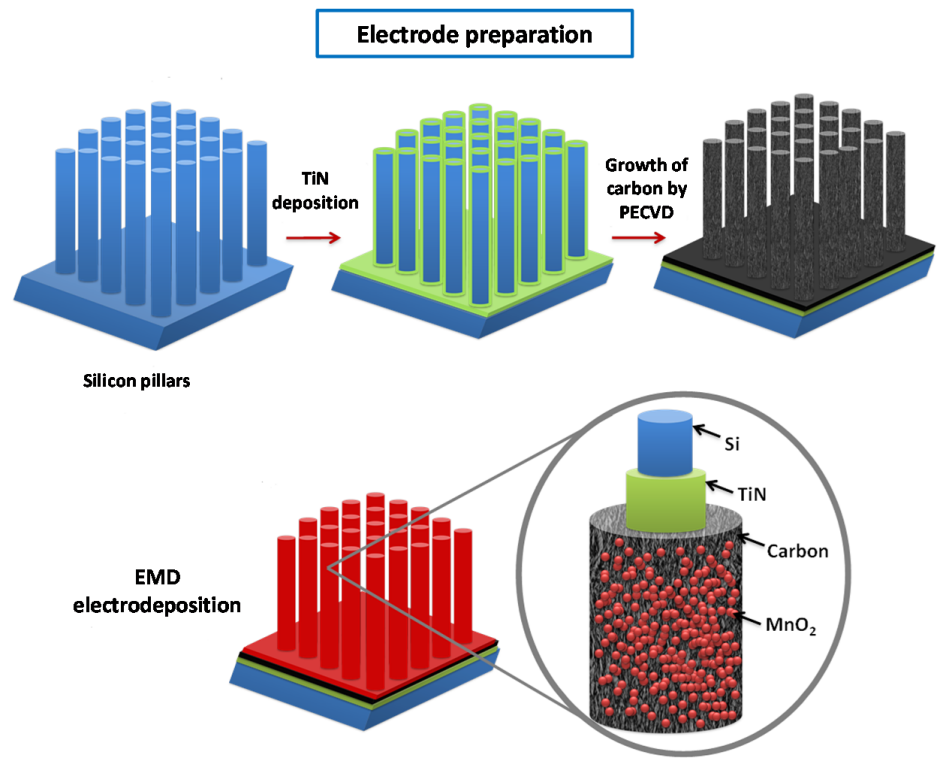

Scheme 2. The steps of electrolytic manganese dioxide (EMD) thin film electrode preparation on $\mathrm{C} / \mathrm{TiN} / \mathrm{Si}$ pillars substrate from an aqueous bath of $\mathrm{MnSO}_{4}$ in $\mathrm{H}_{2} \mathrm{SO}_{4}$. More details will be provided in the experimental section.

\section{Experimental}

\subsection{Fabrication of Silicon Pillar Arrays}

Square arrays of silicon micro-pillars $2 \mu \mathrm{m}$ in diameter with $2 \mu \mathrm{m}$ spacing (or $4 \mu \mathrm{m}$ inter-pillar distance) (Figure 1a,b) were prepared by the Deep Reactive Ion Etching (DRIE) process [54,55]. A $600 \mathrm{~nm} \mathrm{SiO}_{2}$ hard mask was used for 55-60 $\mu \mathrm{m}$ deep etches. The remaining hard mask after DRIE can be seen on top of the pillars in Figure 1c.
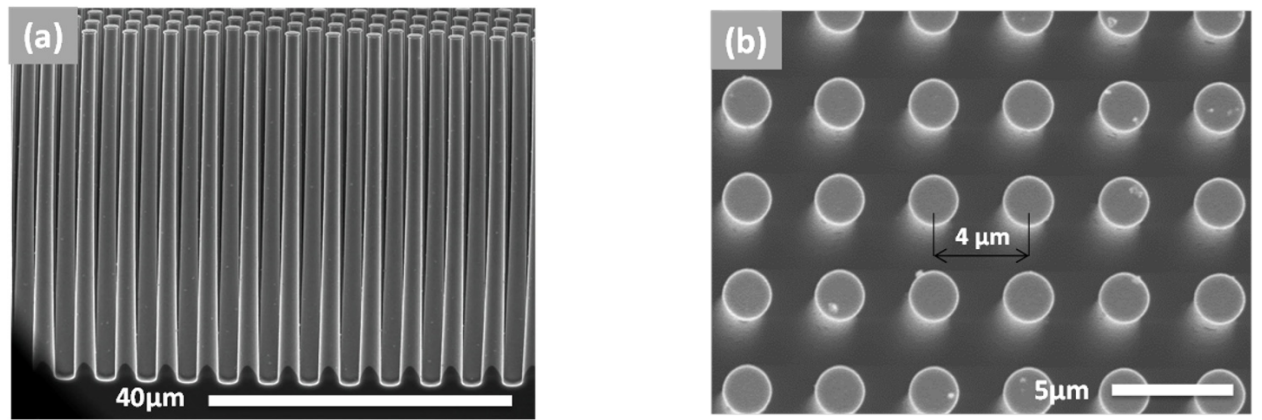

Figure 1. Cont. 


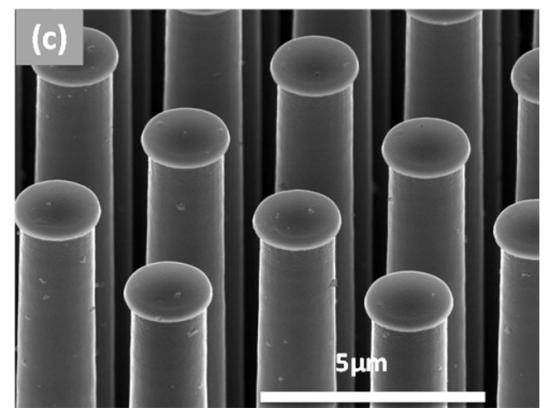

Figure 1. (a) Cross-section, (b) top and (c) tilted view SEM images for TiN coated silicon pillar arrays.

Afterwards, a dry etch step was done to remove the polymeric residues of the DRIE process from the pillar side walls. Then, the obtained Si pillars were coated with $20 \mathrm{~nm}$ TiN film by atomic layer deposition (ALD). These 55-60 $\mu \mathrm{m}$ high pillars give an aspect ratio of 30 with an area enhancement of about $25 \times$.

\subsection{Carbon Coating on TiN/Si Pillars}

The TiN/Si pillars were subsequently coated with 30-50 nm carbon films [56-58]. The carbon deposition is conducted in NANOCVD, a capacitively coupled PE-CVD reactor with a $13.56 \mathrm{MHz}$ Radio Frequency (RF) generator (Oxford Instruments, Bristol, UK). The PE-CVD process was carried out using a $\mathrm{C}_{2} \mathrm{H}_{2}: \mathrm{H}_{2}$ (10:100) mixture at low pressure $\left(0.46\right.$ Torr) and at a temperature of $800{ }^{\circ} \mathrm{C}$. The carbon coating was grown on $20 \mathrm{~nm}$ ALD TiN coated silicon pillars as illustrated in Figure 2. The TiN layer enables the electrical contact for the PE-CVD carbon and serves as a lithium diffusion barrier for the underlying $\mathrm{Si}[51,57]$.

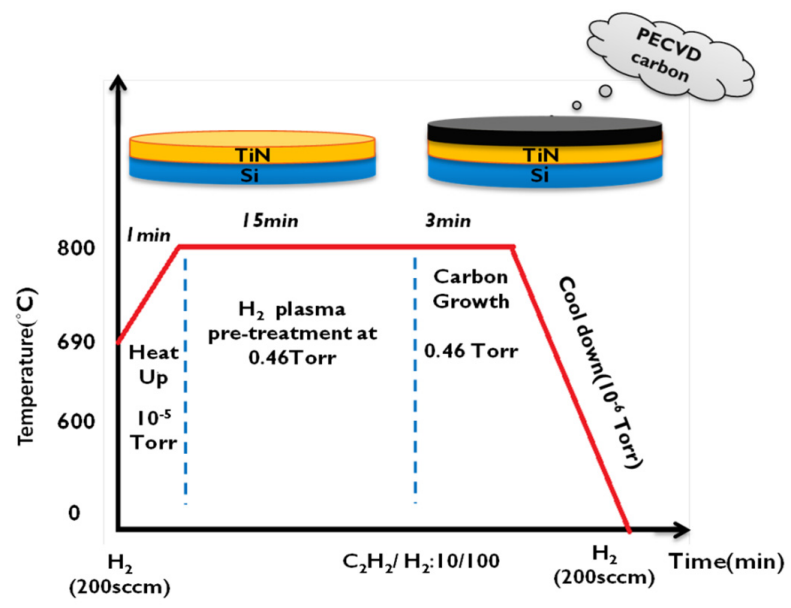

Figure 2. Representation of the process of PECVD carbon deposition and its profile. In this graph, the experimental parameters (Gas flow, temperature setting) are diagrammatically shown.

\subsection{Deposition of EMD Thin Films on Carbon Coated TiN/Si Pillars}

EMD thin films were anodically deposited from an aqueous bath of $(0.3 \mathrm{M}) \mathrm{MnSO}_{4} \cdot \mathrm{H}_{2} \mathrm{O}$ (98.0-101.0\%, Alfa Aeser, Karlsruhe, Germany) and (0.3 M) $\mathrm{H}_{2} \mathrm{SO}_{4}(96 \%$, OM Group ultra-pure chemicals, Cleveland, $\mathrm{OH}, \mathrm{USA})$ at room temperature $\left(20-25^{\circ} \mathrm{C}\right)$ without agitation [10]. In order to investigate the impact of bath deposition temperature on the prepared thin films, the same EMD deposition process was performed in a bath heated to a temperature of $40{ }^{\circ} \mathrm{C}$. All deposition experiments and electrochemical measurements were conducted using Autolab PGSTAT 30 (Metrohm, Utrecht, The Netherlands) or PGSTAT 100 potentiostats (Metrohm, Utrecht, The Netherlands). 
A three-electrode cell was established with Pt mesh (52 mesh woven from $0.1 \mathrm{~mm}$ (0.004 in) diameter wire, 99.9\% (metals basis), $25 \mathrm{~mm} \times 25 \mathrm{~mm}$, supplied by Alfa Aesar Aesar, Karlsruhe, Germany) as a counter electrode (CE) and $\mathrm{Ag} / \mathrm{AgCl} / 3 \mathrm{M} \mathrm{NaCl}$ reference electrode (RE) (BASi analytical, $0.21 \mathrm{~V}$ vs. $\mathrm{SHE}$. In what follows, all potentials are referred to the $\mathrm{Ag} / \mathrm{AgCl}$ electrode unless otherwise noted. The working electrodes (WE) were C/TiN silicon pillar arrays. The area of the WE exposed to the electrolyte was $1 \mathrm{~cm}^{2}$. Before deposition, ohmic contact was made on the back side of the samples by Indium-Gallium (In-Ga).

\subsection{Physical and Electrochemical Characterization of EMD Thin Films}

After deposition, the water content in the EMD films was removed by thermal annealing at $350{ }^{\circ} \mathrm{C}$ in $\mathrm{N}_{2}$ atmosphere (200 mbar) for $3 \mathrm{~h}$ in a vacuum oven (+20 $\mathrm{min}$. ramp-up). The electrochemical activity of EMD films was investigated by cyclic voltammetry $(\mathrm{CV})$ at a scan rate of $10 \mathrm{mV} / \mathrm{s}$ between

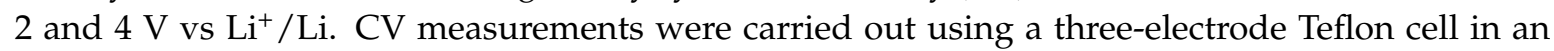
argon-filled glove box ( $<1$ ppm $\mathrm{O}_{2}$ and $\mathrm{H}_{2} \mathrm{O}$ levels). The substrates with EMD films were connected as the working electrode in the same way as for the deposition. Two ribbons of Li metal were used as reference and counter electrodes, respectively. The $\mathrm{Li}^{+}$electrolyte solution was made up of $1 \mathrm{M} \mathrm{LiClO}_{4}$ (99.99\%, Sigma-Aldrich, Overijse, Belgium) in Anhydrous Propylene Carbonate (99.7\%, Sigma-Aldrich, Overijse, Belgium) solvent.

The morphology of EMD films was checked by scanning electron microscopy (SEM) Philips-XL30 ESEM (FEI, Hillsboro, OR, USA).

\section{Results and Discussion}

\subsection{Conformal Electrodeposition of EMD Films on C-Coated TiN/Si Pillars}

Prior to EMD deposition, the benefit of thin carbon films as protective coatings for TiN diffusion barriers on silicon substrates was reported on planar substrates [52]. Carbon coatings with a nano-roughness of a few tens of nanometres were deposited by a PE-CVD process used for the growth of carbon nanosheets (CNS) [58]. In this case, the process was interrupted after the sheet nucleation step resulting in nano-rough carbon films of 30-50 nm thick as depicted in Figure 3a,b.
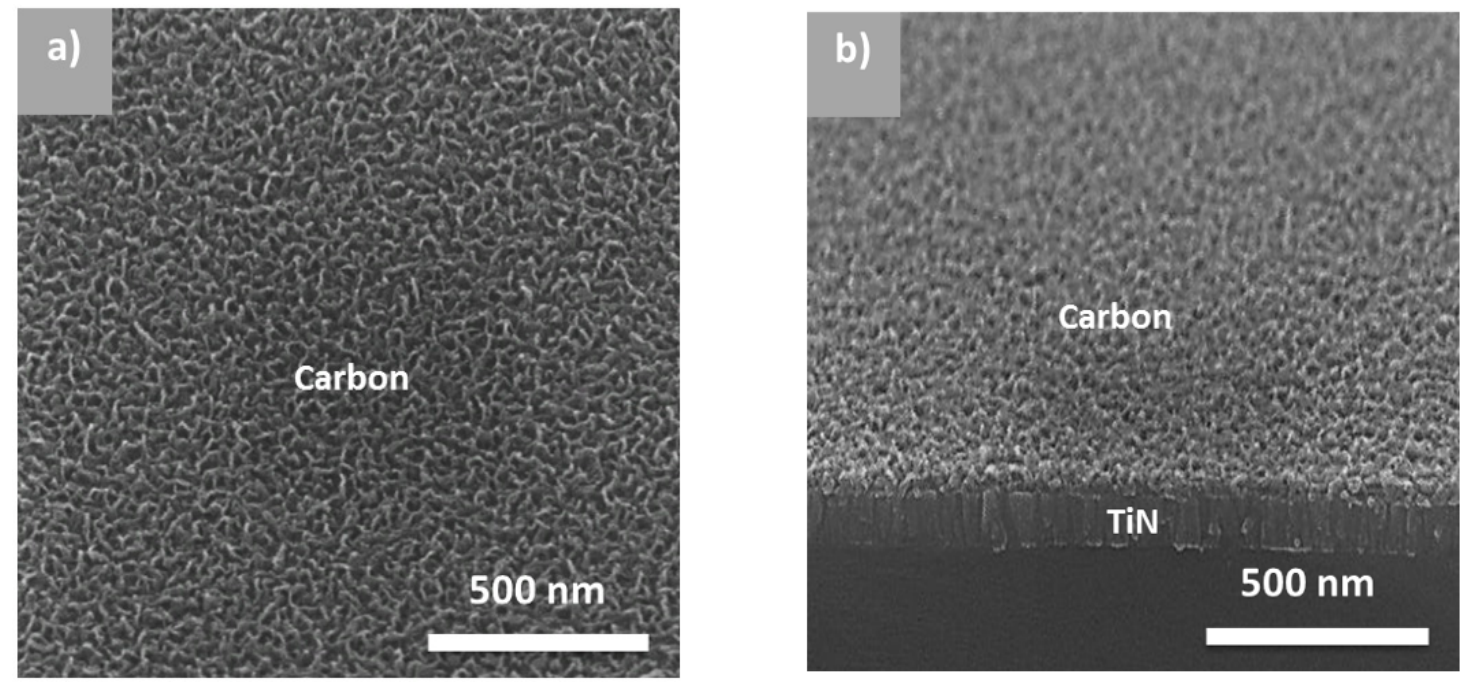

Figure 3. (a) Top and (b) cross-section SEM view of PECVD-carbon layer on $70 \mathrm{~nm}$ TiN/Si substrate.

Further analysis of the as-prepared PE-CVD carbon layer was performed by Raman spectroscopy. As illustrated in Figure 4, the Raman spectrum shows intense bands between 1360 and $1600 \mathrm{~cm}^{-1}$. 


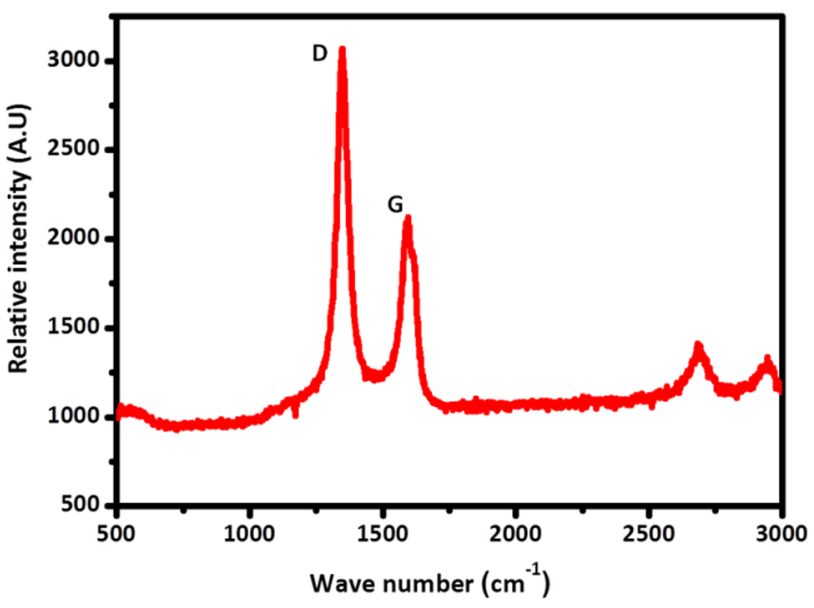

Figure 4. Raman spectrum for $\sim 30-50 \mathrm{~nm}$ PECVD carbon grown on $70 \mathrm{~nm}$ TiN coated silicon substrate at $800{ }^{\circ} \mathrm{C}$ for $3 \mathrm{~min}$.

This carbon coating is a mixture of amorphous carbon (a-C) and graphitic carbon, as reported by Cott et al. [57]. The combination of an intense D-band (bandwidth $\sim 45 \mathrm{~cm}^{-1}$ ) and a lower G-band $\left(\sim 59 \mathrm{~cm}^{-1}\right)$ with a shoulder at $1620 \mathrm{~cm}^{-1}$ indicates the presence of defective graphitic $\left(\mathrm{sp}^{2}\right.$ bonded) carbon. The broad component in the range $1300-1650 \mathrm{~cm}^{-1}$ can be assigned to a-C [59]. This composition of carbon offers a twofold benefit for EMD deposition. The a-C protects the TiN seed layer from oxidation as demonstrated in Ref. [52], while the graphitic portion improves the electrical conductivity of EMD [60].

For Li-ion battery applications, the crystalline carbon is not preferred, as the grain boundary has a low $\mathrm{Li}^{+}$diffusion energy barrier and provides a fast $\mathrm{Li}^{+}$diffusion [60]. Consequently, $\mathrm{Li}^{+}$can be adsorbed at the grain boundaries $[61,62]$. Thus, the electrochemical performance of the electrode stack can be affected. This is why it is interesting to use such a coating with a combination of amorphous and graphitic carbon.

After carbon and EMD deposition, the morphology of the coated high aspect ratio TiN/silicon pillars (Figure $5 \mathrm{a}-\mathrm{c}$ ) was investigated by SEM. Figure $5 \mathrm{~d}-\mathrm{f}$ show cross-sectional SEM images of EMD thin films anodically deposited on the carbon coated silicon pillars from an aqueous bath of $\mathrm{MnSO}_{4}$ $(0.3 \mathrm{M})$ in $\mathrm{H}_{2} \mathrm{SO}_{4}(0.3 \mathrm{M})$ at room temperature $\left(22^{\circ} \mathrm{C}\right)$, without stirring, for $100 \mathrm{~s}$.

The obtained SEM images illustrate conformal and homogenous EMD coatings on the 3D current collector structure. This morphology is due to the effectiveness of the carbon layer on TiN/Si pillars as well as self-limiting electrodeposition of $\mathrm{MnO}_{2}$ active material. A thick film of $230 \mathrm{~nm}$ covers the carbon-coated silicon from top to bottom as exhibited in Figure 5e,f. However, Figure 5d shows some cracks in EMD coating that can be explained by induced internal stresses in its structure. By increasing the bath deposition temperature to $40{ }^{\circ} \mathrm{C}$, the morphology of EMD was improved as it can be seen for the SEM images in Figure $5 \mathrm{~g}-\mathrm{i}$. The cracks previously seen disappeared and the conformal aspect of the coating is kept. However, the thickness of the deposited film is slightly increased to 240 $\mathrm{nm}$ compared to the one deposited at room temperature. In fact, the bath deposition temperature influences the morphology and structural properties of $\mathrm{MnO}_{2}$ deposited by electrolysis as reported by Ghaemi et al. [63].

Under the different deposition studied conditions, EMD film thickness was measured by SEM on top of the pillars (where the layer was broken off due to the cleaving of the sample), in the planar field area next to the pillar array and at the bottom of the pillars. No appreciable difference in EMD thickness was measured proving the excellent conformity of the films. 

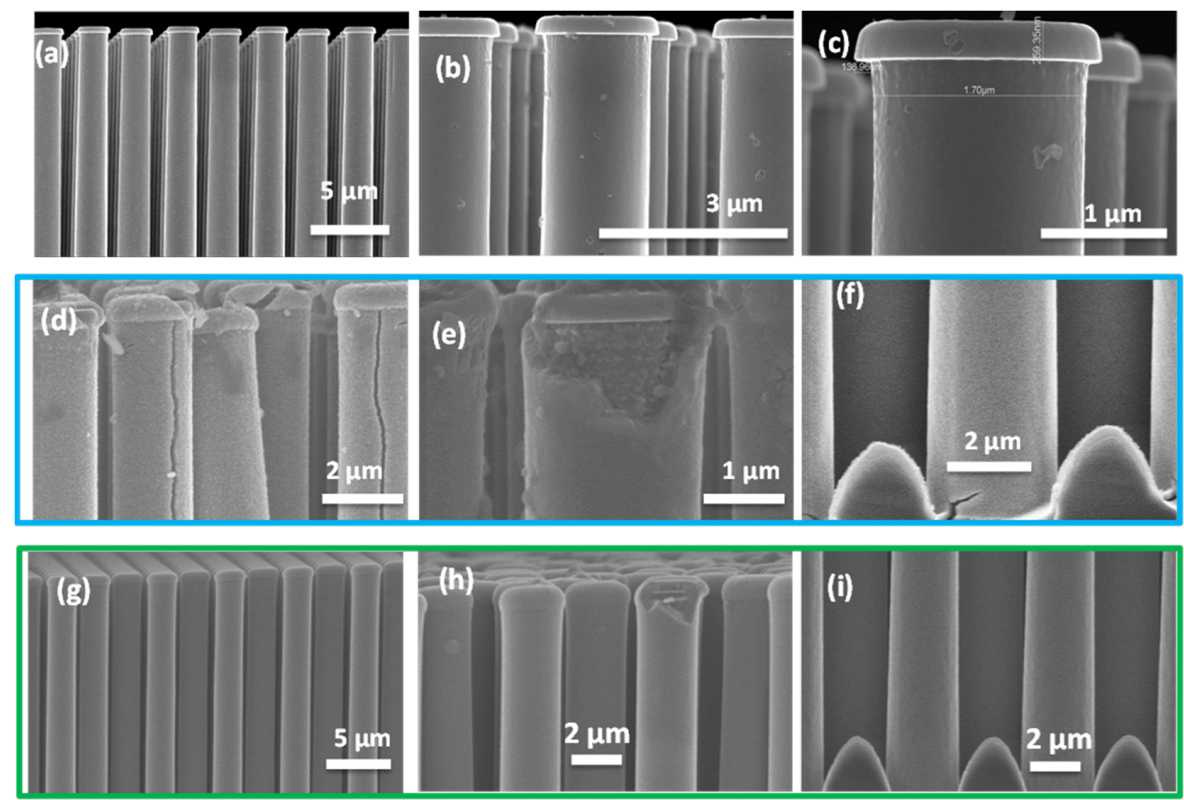

Figure 5. Scanning electron microscopy images showing the TiN silicon pillars $(\mathbf{a}-\mathbf{c})$ before carbon and EMD deposition. Cross-sectional SEM images for EMD anodically deposited on carbon-coated TiN/Si pillars under $4.5 \mathrm{~mA} / \mathrm{cm}^{2}$ (effective current $0.2 \mathrm{~mA} / \mathrm{cm}^{2}$ ) for $100 \mathrm{~s}$ at room temperature of $22{ }^{\circ} \mathrm{C} ;(\mathbf{d}-\mathbf{f})$ and at a bath temperature of $40{ }^{\circ} \mathrm{C} ;(\mathbf{g}-\mathbf{i})$. All EMD films were deposited from an aqueous bath of $\mathrm{MnSO}_{4}(0.3 \mathrm{M})$ in $\mathrm{H}_{2} \mathrm{SO}_{4}(0.3 \mathrm{M})$, without agitation.

Figure 6 shows the variation of the average film thickness with deposition time together with the expected thickness in the case of dense $\mathrm{MnO}_{2}$ thin films based on Faraday's law of electrolysis:

$$
\text { Theoritical thickness }=\frac{\mathrm{MW}_{\mathrm{MnO}_{2}} \times i_{d} \times t}{F \times n \times \rho_{\mathrm{MnO}_{2}}}
$$

where $\mathrm{MW}_{\mathrm{MnO}_{2}}=86.93 \mathrm{~g} / \mathrm{mol}$ is the molecular weight of $\mathrm{MnO}_{2}, i_{d}$ the applied current density in $\mathrm{A} / \mathrm{cm}^{2}, t$ is the deposition time in seconds (s), $F=96,485 \mathrm{C} / \mathrm{mol}$ is Faraday's constant, $n=2$ the number of electrons exchanged during the oxidation reaction and $\rho_{\mathrm{MnO}_{2}}=5.03 \mathrm{~g} / \mathrm{cm}^{3}$ is the density of $\mathrm{MnO}_{2}$.

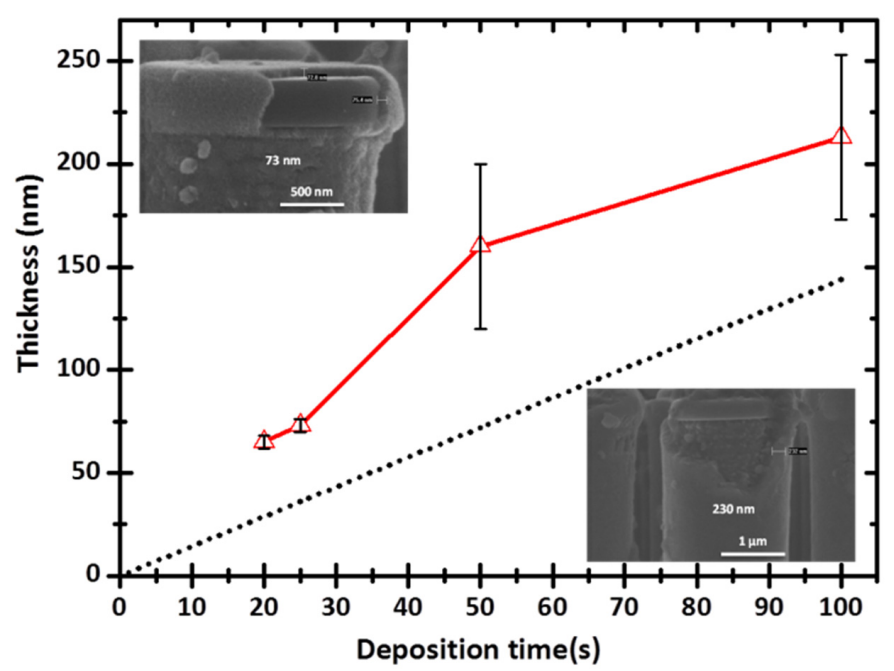

Figure 6. Theoretical thickness (dotted line) and experimental thickness (full line) vs. deposition time for EMD deposited at $4.5 \mathrm{~mA} / \mathrm{cm}^{2}$ on carbon coated 3D pillar arrays with an area enhancement of $25 \times$. 
As depicted in Figure 6, the film thickness increases linearly with deposition time up to $1 \mathrm{~min}$. It should be noted that the difference between theoretical thickness and actual measured EMD film thickness is of factor two as found for planar films with the expected porosity of $\sim 50 \%$ [51,52]. This discrepancy in the film thickness is explained by the fact that EMD films are highly porous in nature. The porosity of $\mathrm{MnO}_{2}$ is important for charge transfer during deposition [64]. However, at high charge density, the effective current density drops, resulting in a subsequent drop in the degree of porosity.

The deviation from linearity for $t>50 \mathrm{~s}$ is likely due to a decrease in current efficiency when parasitic oxygen evolution reaction kicks in as reported in Ref. [51]. Moreover, high experimental thickness values could be attributed to the trapped water in EMD films structure during deposition as demonstrated by Johns et al. [65].

\subsection{Electrochemical Lithiation/Delithiation Properties of EMD Deposited on C/TiN/Si Pillars}

The electrochemical behavior of the annealed EMD films, at $350{ }^{\circ} \mathrm{C}$ in $\mathrm{N}_{2}$ atmosphere, was examined by cyclic voltammetry in $1 \mathrm{M} \mathrm{LiClO}_{4} / \mathrm{PC}$ battery electrolyte between 2 and $4 \mathrm{~V} \mathrm{vs.} \mathrm{Li}^{+} / \mathrm{Li}$.

Figure 7a shows the recorded voltammograms of $230 \mathrm{~nm}$-thick EMD film deposited on C/TiN/Si pillars at room temperature. The second cycle did not show any reversible current peaks for lithium ions insertion/extraction. However, a purely capacitive wave current response was observed. This poor electrochemical response is likely due to a decrease in the electrolyte access to the film, as well as an increase in the electronic resistance [66]. Upon cycling, the peak current slightly increases to reach its maximum by the 70th cycle and drops again as seen in the 100th cycle. This behavior highlights the impact of the overall resistance resulting in ohmic drop (IR) that affects the electrode performance. In this case, EMD coatings with such properties can be successfully used for electrochemical capacitors [67-69].
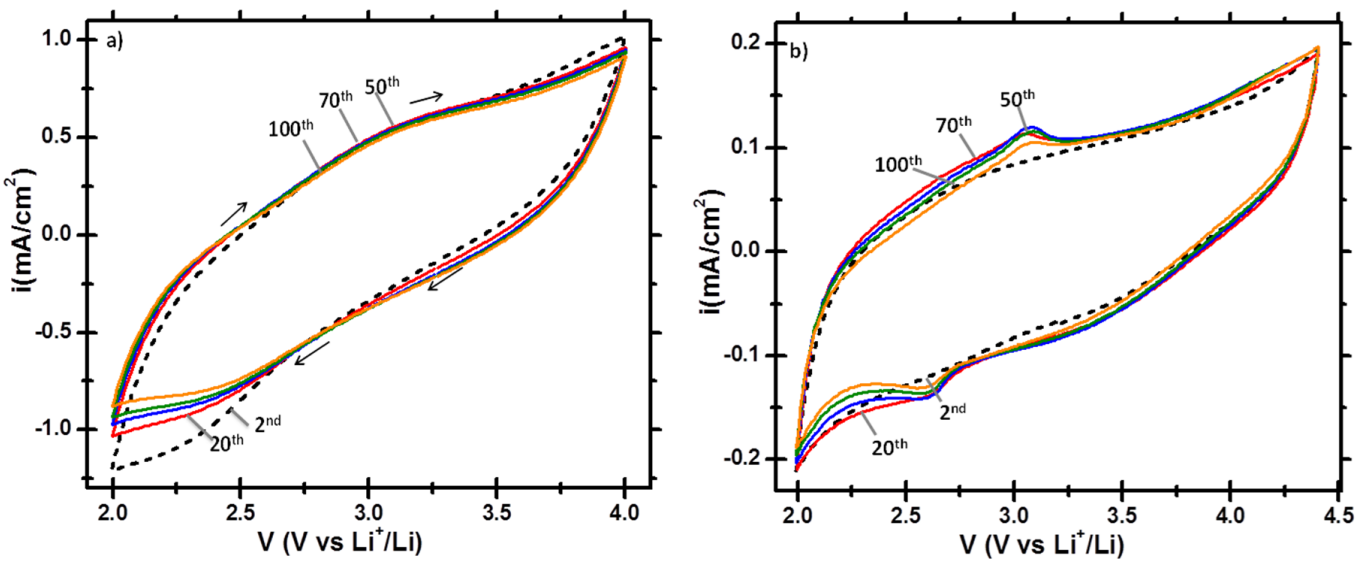

Figure 7. Cyclic voltammograms for Li-ion insertion (cathodic) and extraction (anodic) for (a) $230 \mathrm{~nm}$ EMD and (b) $70 \mathrm{~nm}$ EMD anodically deposited on C/TiN/Si pillars obtained in $1 \mathrm{M} \mathrm{LiClO}_{4} /$ propylene carbonate at a scan rate of $10 \mathrm{mVs}^{-1}$. Cycles 2, 20,50,70 and 100 are shown for a total of 100 consecutive cycles. The EMD films were deposited at $4.5 \mathrm{~mA} / \mathrm{cm}^{-2}$ and annealed at $350{ }^{\circ} \mathrm{C}$ in $\mathrm{N}_{2}$ atmosphere for three hours.

Figure $7 \mathrm{~b}$ illustrates the voltammograms of $70 \mathrm{~nm}$ EMD deposited on C/TiN/Si pillars. The film was also not electrochemically activated at the second cycle. At a scan rate of $10 \mathrm{mV} / \mathrm{s}, \mathrm{Li}^{+}$does not have enough time to diffuse inside the film at the beginning of cycling. However, the magnitude of the peak current was relatively increased upon cycling. This could be attributed to improvement in $\mathrm{Li}^{+}$intercalation kinetics of the EMD film. Small broad peaks appeared from the 10th cycle at 2.6 and $3.05 \mathrm{~V} \mathrm{vs}$. $\mathrm{Li}^{+} / \mathrm{Li}$, respectively. This electrochemical response of EMD thin-films is in agreement with previous findings $[10,70,71]$ : 


$$
\mathrm{MnO}_{2}+x \mathrm{Li}^{+}+x \mathrm{e}^{-} \rightleftharpoons \mathrm{Li}_{x} \mathrm{MnO}_{2}
$$

The insertion of $\mathrm{Li}^{+}$was accompanied with the reduction of Mn(IV) to $\mathrm{Mn}(\mathrm{III})$ in the EMD films. In the reverse scan, the $\mathrm{Li}^{+}$are extracted upon the re-oxidation of $\mathrm{Mn}(\mathrm{III})$ to $\mathrm{Mn}(\mathrm{IV})$ [51]. The improved $\mathrm{Li}^{+}$diffusion, in $70 \mathrm{~nm}$ EMD film, can be explained by several factors. For instance, the decreased thickness implies a decrease in the overall resistance. This consequently compensates for the IR drop and leads to increasing the film porosity. However, the electrochemical activity faded after the 50th cycle for the $230 \mathrm{~nm}$ EMD film. Side reactions at the electrode/liquid electrolyte interface as well as $\mathrm{Li}^{+}$ diffusion kinetics limitations might suppress the activity of EMD thin film [72,73]. Furthermore, the composition of the film could be influenced by the deposition conditions of electrodeposition as time and charge density. Consequently, the percentage of each species within the heat-treated EMD has an effect on its electrochemical performance. Dose et al. reported that the relationship between Mn(IV) and $\mathrm{Mn}(\mathrm{III})$ is inversely proportional, as low $\mathrm{Mn}(\mathrm{IV})$ entails high $\mathrm{Mn}(\mathrm{III})$, resulting in a decrease in the performance of the electrode [74,75]:

$$
\mathrm{Mn}^{I V} \mathrm{O}_{2}+x \mathrm{e}^{-}+x \mathrm{Li}^{+} \leftrightharpoons \mathrm{Li}_{x} \mathrm{Mn}_{x}^{I I I} \mathrm{Mn}_{1-x}^{I V} \mathrm{O}_{2}
$$

Figure 8 presents the recorded voltammograms of $240 \mathrm{~nm}$ EMD deposited on C/TiN/Si pillars at $40{ }^{\circ} \mathrm{C}$. These measurements had a goal of making use of the conformal thick film deposited over carbon coated pillar arrays while evaluating the influence of bath deposition temperature on its electrochemical performance.

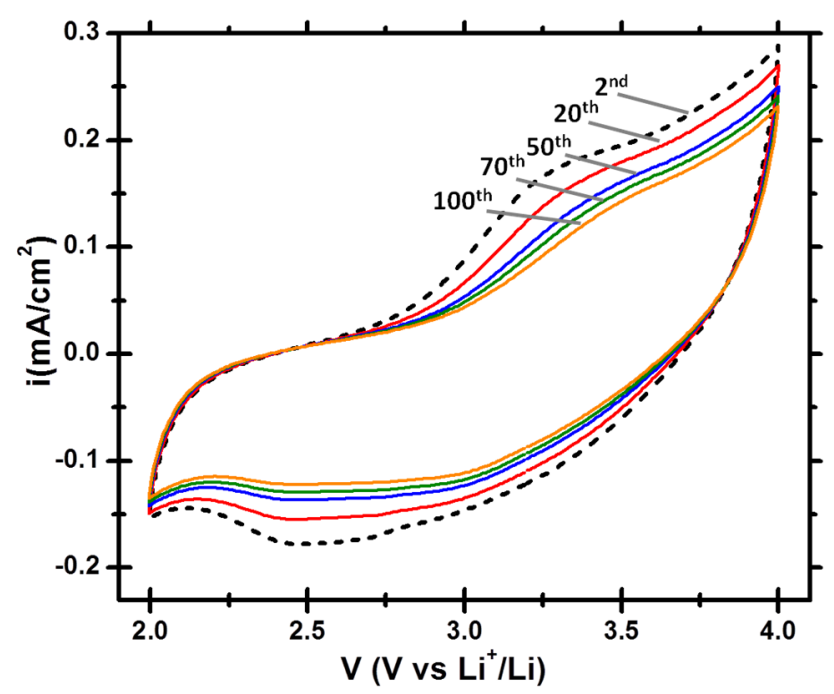

Figure 8. Cyclic voltammograms for Li-ion insertion and extraction for $240 \mathrm{~nm}$ EMD anodically deposited on $\mathrm{C} / \mathrm{TiN} / \mathrm{Si}$ pillars obtained in $1 \mathrm{M} \mathrm{LiClO}_{4}$ in propylene carbonate at a scan rate of $10 \mathrm{mVs}^{-1}$ - Cycles 2, 20, 50,70 and 100 are shown for a total of 100 consecutive cycles. The EMD films were deposited at $4.5 \mathrm{~mA} / \mathrm{cm}^{2} \mathrm{~s}$ at $40^{\circ} \mathrm{C}$. After the deposition, the annealing step is made at $350{ }^{\circ} \mathrm{C}$ for three hours in $\mathrm{N}_{2}$ atmosphere to enable the lithiation.

Perversely to the EMD film prepared at room temperature, the deposited film at $40{ }^{\circ} \mathrm{C}$ exhibited a capacitive current response from the second cycle with small broad peaks of electrochemical activity at 2.5 and $3.25 \mathrm{~V}$ vs. $\mathrm{Li}^{+} / \mathrm{Li}$, respectively. However, the electrochemical performance faded upon cycling. This is likely due to $\mathrm{Li}^{+}$diffusion limitations and/or to the remaining water content in EMD [65], resulting in the formation of secondary products like $\mathrm{MnOOH}$ [38]. Such a product could be dissolved, releasing $\mathrm{Mn}$ (III) ions to the electrolyte and reduced to Mn(II) species later on [76]. This partial dissolution of EMD films into the electrolyte during cycling can explain the poor electrochemical 
behavior noted in Figure 8. The use of additives, such as $\mathrm{TiB}_{2}$, to the deposited film and the optimization of the heat-treatment before lithium intercalation are recommended [76,77].

\section{Conclusions}

In summary, we have achieved conformal EMD films on high aspect ratio carbon coated TiN/Si pillars by means of electrochemical deposition (ECD). The use of a thin carbon buffer layer on 3D TiN/Si pillar arrays has been found to be advantageous due to its composition consisting of graphitic and amorphous carbon enabling the deposition of $\gamma-\mathrm{MnO}_{2}$ on the 3D current collector stack with good adhesion and without the oxidation of the underlying ALD TiN layer. The electrochemical performance of the deposited films, in terms of $\mathrm{Li}^{+}$insertion/extraction, depends on $\gamma-\mathrm{MnO}_{2}$ characteristics such as thickness and porosity. Even though no apparent morphological differences were found between EMD films prepared at different bath temperatures, their electrochemical activity implies that the composition might not be the same. Therefore, further optimization for the post-deposition thermal treatment should be addressed to get more insights on the relationship between the compositional changes of EMD films and their electrochemical behavior on the 3D C/TiN/Si pillars.

Acknowledgments: The authors acknowledge the partial financial support by the Flemish Instituut voor Innovatie door Wetenschap en Technologie IWT through the Strategisch Basisonderzoek SBO project SOS-Lion (2012/5416). We thank Maarten Mees for the battery schematic and Marcel Lux for SEM measurements.

Author Contributions: Yafa Zargouni, Alex Radisic, and Philippe Vereecken designed the experiments, Yafa Zargouni and Stella Deheryan performed the experiments, Yafa Zargouni analyzed data and wrote the paper, Alex Radisic and Philippe Vereecken supervised experiments and commented on the data, and Khaled Alouani commented on the data. All authors discussed the results and commented on the manuscript at all stages.

Conflicts of Interest: The authors declare no conflict of interest.

\section{References}

1. Roberts, M.; Johns, P.; Owen, J.; Brandell, D.; Edstrom, K.; El Enany, G.; Guery, C.; Golodnitsky, D.; Lacey, M.; Lecoeur, C.; et al. 3D Lithium Ion Batteries-From Fundamentals to Fabrication. J. Mater. Chem. 2011, 21, 9876-9890. [CrossRef]

2. Scrosati, B.; Garche, J. Lithium Batteries: Status, Prospects and Future. J. Power Sources 2010, 195, 2419-2430. [CrossRef]

3. Aricò, A.S.; Bruce, P.; Scrosati, B.; Tarascon, J.-M.; Schalkwijk, V.W. Nanostructured Materials for Advanced Energy Conversion and Storage Devices. Nat. Mater. 2005, 4, 366-377. [CrossRef] [PubMed]

4. Wang, Y.; Liu, B.; Li, Q.; Cartmell, S.; Ferrara, S.; Deng, Z.D.; Xiao, J. Lithium and Lithium Ion Batteries for Applications in Microelectronic Devices: A Review. J. Power Sources 2015, 286, 330-345. [CrossRef]

5. Vereecken, P.M.; Huyghebaert, C. Conformal Deposition For 3D Thin-Film Batteries. ECS Trans. 2013, 58, 111-118. [CrossRef]

6. Armand, M.; Tarascon, J.-M. Building Better Batteries. Nature 2008, 451, 652-657. [CrossRef] [PubMed]

7. Arthur, T.S.; Bates, D.J.; Cirigliano, N.; Johnson, D.C.; Malati, P.; Mosby, J.M.; Perre, E.; Rawls, M.T.; Prieto, A.L.; Dunn, B. Three-Dimensional Electrodes and Battery Architectures. MRS Bull. 2011, 36, 523-531. [CrossRef]

8. Valvo, M.; Roberts, M.; Oltean, G.; Sun, B.; Rehnlund, D.; Brandell, D.; Nyholm, L.; Gustafsson, T.; Edström, K. Electrochemical Elaboration of Electrodes and Electrolytes for 3D Structured Batteries. J. Mater. Chem. A 2013, 1, 9281-9293. [CrossRef]

9. Oltean, G.; Valvo, M.; Nyholm, L.; Edström, K. On the Electrophoretic and Sol-Gel Deposition of Active Materials on Aluminium Rod Current Collectors for Three-Dimensional Li-Ion Micro-Batteries. Thin Solid Films 2014, 562, 63-69. [CrossRef]

10. Zargouni, Y.; Deheryan, S.; Radisic, A.; Cott, D.J.; Rochan, S.; Alouani, K.; Huyghebaert, C.; Vereecken, P.M. Electrodeposition and Characterization of Manganese Dioxide Thin Films on Silicon Pillar Arrays for 3D Thin-Film Lithium-Ion Batteries. ECS Trans. 2014, 61, 29-41. [CrossRef]

11. Oltean, G.; Asfaw, H.D.; Nyholm, L.; Edstrom, K. A Li-Ion Microbattery with 3D Electrodes of Different Geometries. ECS Electrochem. Lett. 2014, 3, A54-A57. [CrossRef] 
12. Rehnlund, D.; Valvo, M.; Edstrom, K.; Nyholm, L. Electrodeposition of Vanadium Oxide/Manganese Oxide Hybrid Thin Films on Nanostructured Aluminum Substrates. J. Electrochem. Soc. 2014, 161, D515-D521. [CrossRef]

13. Su, X.; Wu, Q.; Li, J.; Xiao, X.; Lott, A.; Lu, W.; Sheldon, B.W.; Wu, J. Silicon-Based Nanomaterials for Lithium-Ion Batteries: A Review. Adv. Energy Mater. 2014, 4, 1-23. [CrossRef]

14. Gambino, J.P.; Adderly, S.A.; Knickerbocker, J.U. An Overview of Through-Silicon-via Technology and Manufacturing Challenges. Microelectron. Eng. 2015, 135, 73-106. [CrossRef]

15. Chamran, F.; Yeh, Y.; Min, H.; Dunn, B.; Kim, C. Fabrication of High-Aspect-Ratio Electrode Arrays for Three-Dimensional Microbatteries. J. Microelectromechanical Syst. 2007, 16, 844-852. [CrossRef]

16. Wang, C.; Taherabadi, L.; Jia, G.; Kassegne, S.; Zoval, J.V.; Madou, M.J. Carbon-MEMS Architectures for 3D Microbatteries. Proc. SPIE 2004, 5455, 295-302. [CrossRef]

17. Notten, B.P.H.L.; Roozeboom, F.; Niessen, R.A.H.; Baggetto, L. 3-D Integrated All-Solid-State Rechargeable Batteries. Adv. Mater. 2007, 19, 4564-4567. [CrossRef]

18. Whitehead, A.H.; Schreiber, M. Current Collectors for Positive Electrodes of Lithium-Based Batteries. J. Electrochem. Soc. 2005, 152, A2105. [CrossRef]

19. Kim, S.W.; Cho, K.Y. Current Collectors for Flexible Lithium Ion Batteries: A Review of Materials. J. Electrochem. Sci. Technol. 2015, 6, 1-6. [CrossRef]

20. Freixas, J.; Eustache, E.; Roussel, P.; Brillard, C.; Deresmes, D.; Nuns, N.; Rolland, N.; Brousse, T.; Lethien, C. Sputtered Titanium Nitride: A Bifunctional Material for Li-Ion Microbatteries. J. Electrochem. Soc. 2015, 162, 493-500. [CrossRef]

21. Oudenhoven, J.F.M.; Baggetto, L.; Notten, P.H.L. All-Solid-State Lithium-Ion Microbatteries: A Review of Various Three-Dimensional Concepts. Adv. Energy Mater. 2011, 1, 10-33. [CrossRef]

22. Lukatskaya, M.R.; Dunn, B.; Gogotsi, Y. Architectures for Future Hybrid Energy Storage. Nat. Commun. 2016, 7, 1-13. [CrossRef] [PubMed]

23. Golodnitsky, D.; Nathan, M.; Yufit, V.; Strauss, E.; Freedman, K.; Burstein, L.; Gladkich, A.; Peled, E. Progress in Three-Dimensional (3D) Li-Ion Microbatteries. Solid State Ionics 2006, 177, 2811-2819. [CrossRef]

24. Taberna, P.L.; Mitra, S.; Poizot, P.; Simon, P.; Tarascon, J.-M. High Rate Capabilities $\mathrm{Fe}_{3} \mathrm{O}_{4}$-Based $\mathrm{Cu}$ Nano-Architectured Electrodes for Lithium-Ion Battery Applications. Nat. Mater. 2006, 5, 567-573. [CrossRef] [PubMed]

25. Gowda, S.R.; Leela Mohana Reddy, A.; Zhan, X.; Ajayan, P.M. Building Energy Storage Device on a Single Nanowire. Nano Lett. 2011, 11, 3329-3333. [CrossRef] [PubMed]

26. Duan, H.; Gnanaraj, J.; Liang, J. Synthesis and Rate Performance of $\mathrm{Fe}_{3} \mathrm{O}_{4}$-Based Cu Nanostructured Electrodes for Li-Ion Batteries. J. Power Sources 2011, 196, 4779-4784. [CrossRef]

27. Moitzheim, S.; Nimisha, C.S.; Deng, S.; Cott, D.J.; Detavernier, C.; Vereecken, P.M. Nanostructured $\mathrm{TiO}_{2}$ / carbon Nanosheet Hybrid Electrode for High-Rate Thin-Film Lithium-Ion Batteries. Nanotechnology 2014, 25, 504008. [CrossRef] [PubMed]

28. Edström, K.; Brandell, D.; Gustafsson, T.; Nyholm, L. Electrodeposition as a Tool for 3D Microbattery Fabrication. Electrochem. Soc. Interface 2011, 20, 41-46. [CrossRef]

29. Knoops, H.C.M.; Donders, M.E.; van de Sanden, M.C.M.; Notten, P.H.L.; Kessels, W.M.M. Atomic Layer Deposition for Nanostructured Li-Ion Batteries. J. Vac. Sci. Technol. A Vac. Surf. Film. 2012, 30, 10801. [CrossRef]

30. Liu, J.; Sun, X. Elegant Design of Electrode and Electrode/electrolyte Interface in Lithium-Ion Batteries by Atomic Layer Deposition. Nanotechnology 2015, 26, 24001. [CrossRef] [PubMed]

31. Wang, X.; Yushin, G. Chemical Vapor Deposition and Atomic Layer Deposition for Advanced Lithium Ion Batteries and Supercapacitors. Energy Environ. Sci. 2015, 8, 1889-1904. [CrossRef]

32. Li, X.; Liu, J.; Meng, X.; Tang, Y.; Banis, M.N.; Yang, J.; Hu, Y.; Li, R.; Cai, M.; Sun, X. Significant Impact on Cathode Performance of Lithium-Ion Batteries by Precisely Controlled Metal Oxide Nanocoatings via Atomic Layer Deposition. J. Power Sources 2014, 247, 57-69. [CrossRef]

33. Aaltonen, T.; Nilsen, O.; Magras, A.; Fjellv, H. Atomic Layer Deposition of $\mathrm{Li}_{2} \mathrm{O}-\mathrm{Al}_{2} \mathrm{O}_{3}$ Thin Films. Chem. Mater. 2011, 23, 4669-4675. [CrossRef]

34. Thackeray, M.M. Manganese Oxides for Lithium Batteries. Prog. Solid State Chem. 1997, 25, 1-71. [CrossRef]

35. Reddy, A.L.M.; Shaijumon, M.M.; Gowda, S.R.; Ajayan, P.M. Coaxial $\mathrm{MnO}_{2}$ /carbon Nanotube Array Electrodes for High-Performance Lithium Batteries. Nano Lett. 2009, 9, 1002-1006. [CrossRef] [PubMed] 
36. Garcia, E.; Lins, V.; Matencio, T. Metallic and Oxide Electrodeposition. Mod. Surf. Eng. Treat. 2013, 101-122. [CrossRef]

37. He, X.; Wang, L.; Pu, W.; Zhang, G.; Jiang, C.; Wan, C. Synthesis of Spinel $\mathrm{LiMn}_{2} \mathrm{O}_{4}$ for Li-Ion Batteries via Sol-Gel Process. Int. J. Electrochem. Soc. 2006, 1, 12-16.

38. Biswal, A.; Chandra Tripathy, B.; Sanjay, K.; Subbaiah, T.; Minakshi, M. Electrolytic Manganese Dioxide (EMD): A Perspective on Worldwide Production, Reserves and Its Role in Electrochemistry. RSC Adv. 2015, 5, 58255-58283. [CrossRef]

39. Scrosati, B. Recent Advances in Lithium Solid State Batteries. J. Appl. Electrochem. 1972, 2, 231-238. [CrossRef]

40. Chabre, Y.; Pannetier, J. Structural and Electrochemical Properties of the Proton $/ \gamma-\mathrm{MnO}_{2}$ System. Prog. Solid State Chem. 1995, 23, 1-130. [CrossRef]

41. Ammundsen, B.; Paulsen, J. Novel Lithium-Ion Cathode Materials Based on Layered Manganese Oxides. Adv. Mater. 2001, 13, 943-956. [CrossRef]

42. Dupont, M.F.; Donne, S.W. Nucleation and Growth of Electrodeposited Manganese Dioxide for Electrochemical Capacitors. Electrochim. Acta 2014, 120, 219-225. [CrossRef]

43. Minakshi Sundaram, M.; Biswal, A.; Mitchell, D.; Jones, R.; Fernandez, C. Correlation among Physical and Electrochemical Behaviour of Nanostructured Electrolytic Manganese Dioxide from Leach Liquor and Synthetic for Aqueous Asymmetric Capacitor. Phys. Chem. Chem. Phys. 2016, 18, 4711-4720. [CrossRef] [PubMed]

44. Dubal, D.P.; Aradilla, D.; Bidan, G.; Gentile, P.; Schubert, T.J.S.; Wimberg, J.; Sadki, S.; Gomez-Romero, P. 3D Hierarchical Assembly of Ultrathin $\mathrm{MnO}_{2}$ Nanoflakes on Silicon Nanowires for High Performance Micro-Supercapacitors in Li-Doped Ionic Liquid. Sci. Rep. 2015, 5, 9771. [CrossRef] [PubMed]

45. Ramírez, A.; Hillebrand, P.; Stellmach, D.; May, M.M.; Bogdanoff, P.; Fiechter, S. Evaluation of $\mathrm{MnO}_{X}, \mathrm{Mn}_{2} \mathrm{O}_{3}$, and $\mathrm{Mn}_{3} \mathrm{O}_{4}$ Electrodeposited Films for the Oxygen Evolution Reaction of Water. J. Phys. Chem. C 2014, 118, 14073-14081. [CrossRef]

46. Roche, I.; Chaînet, E.; Chatenet, M.; Vondrák, J. Durability of Carbon-Supported Manganese Oxide Nanoparticles for the Oxygen Reduction Reaction (ORR) in Alkaline Medium. J. Appl. Electrochem. 2008, 38, 1195-1201. [CrossRef]

47. Thackeray, M.M.; Rossouw, M.H.; de Kock, A.; de la Harpe, A.P.; Gummow, R.J.; Pearce, K.; Liles, D.C. The Versatility of $\mathrm{MnO}_{2}$ for Lithium Battery Applications. J. Power Sources 1993, 43, 289-300. [CrossRef]

48. Dose, W.M.; Donne, S.W. Thermal Treatment Effects on Manganese Dioxide Structure, Morphology and Electrochemical Performance. J. Electrochem. Soc. 2011, 158, A905. [CrossRef]

49. Dose, W.M.; Donne, S.W. Kinetic Analysis of $\gamma-\mathrm{MnO}_{2}$ Thermal Treatment. J. Therm. Anal. Calorim. 2011, 105, 113-122. [CrossRef]

50. Paik, Y.; Bowden, W.; Richards, T.; Grey, C.P. The Effect of Heat-Treatment on Electrolytic Manganese Dioxide: A ${ }^{2} \mathrm{H}$ and ${ }^{6} \mathrm{Li}$ Magic Angle Spinning NMR Study. J. Electrochem. Soc. 2005, 152, A1539-A1547. [CrossRef]

51. Etman, A.S.; Radisic, A.; Emara, M.M.; Huyghebaert, C.; Vereecken, P.M. Effect of Film Morphology on the Li-Ion Intercalation Kinetics in Anodic Porous Manganese Dioxide Thin Films. J. Phys. Chem. C 2014, 118, 9889-9898. [CrossRef]

52. Deheryan, S.; Zargouni, Y.; Sinha, R.; Put, B.; Radisic, A.; Heyns, M.; Vereecken, P.M. Nanometer-Thin Graphitic Carbon Buffer Layers for Electrolytic $\mathrm{MnO}_{2}$ for Thin-Film Energy Storage Devices. J. Electrochem. Soc. 2017, 164, A538-A544. [CrossRef]

53. Biswal, A.; Minakshi, M.; Tripathy, B.C. Electrodeposition of Sea Urchin and Cauliflower-like Nickel-/Cobalt-Doped Manganese Dioxide Hierarchical Nanostructures with Improved Energy-Storage Behavior. ChemElectroChem 2016, 3, 976-985. [CrossRef]

54. Li, W.; Zhao, W.; Sun, P. Fabrication of Highly Ordered Metallic Arrays and Silicon Pillars with Controllable Size Using Nanosphere Lithography. Phys. E-Low-Dimensional Syst. Nanostruct. 2009, 41, 1600-1603. [CrossRef]

55. Eustache, E.; Douard, C.; Retoux, R.; Lethien, C.; Brousse, T. $\mathrm{MnO}_{2}$ Thin Films on 3D Scaffold: Microsupercapacitor Electrodes Competing with "Bulk" Carbon Electrodes. Adv. Energy Mater. 2015, 5, 4564-4567. [CrossRef]

56. Deheryan, S.; Cott, D.J.; Mertens, P.W.; Heyns, M.; Vereecken, P.M. Direct Correlation between the Measured Electrochemical Capacitance, Wettability and Surface Functional Groups of CarbonNanosheets. Electrochim. Acta 2014, 132, 574-582. [CrossRef] 
57. Cott, D.J.; Verheijen, M.; Richard, O.; Radu, I.; de Gendt, S.; van Elshocht, S.; Vereecken, P.M. Synthesis of Large Area Carbon Nanosheets for Energy Storage Applications. Carbon 2013, 58, 59-65. [CrossRef]

58. Qaid, M.; Put, B.; Cott, D.J.; AlSalhi, M.S.; Stesmans, A.; Vereecken, P.M.; Radu, I.P. Large Area Carbon Nanosheet Capacitors. ECS Solid State Lett. 2014, 3, N8-N10. [CrossRef]

59. Baddour-Hadjean, R.; Pereira-Ramos, J.-P. Raman Microspectrometry Applied to the Study of Electrode Materials for Lithium Batteries. Chem. Rev. 2010, 110, 1278-1319. [CrossRef] [PubMed]

60. Perez, I.; Corso, B.L.; Khalap, V.R.; Collins, P.G. Conformal $\mathrm{MnO}_{2}$ Electrodeposition onto Defect-Free Graphitic Carbons. Electrochem. Commun. 2011, 13, 590-592. [CrossRef]

61. Park, M.; Zhang, X.; Chung, M.; Less, G.B.; Sastry, A.M. A Review of Conduction Phenomena in Li-Ion Batteries. J. Power Sources 2010, 195, 7904-7929. [CrossRef]

62. Yao, F.; Güneş, F.; Ta, H.Q.; Lee, S.M.; Chae, S.J.; Sheem, K.Y.; Cojocaru, C.S.; Xie, S.S.; Lee, Y.H. Diffusion Mechanism of Lithium Ion through Basal Plane of Layered Graphene. J. Am. Chem. Soc. 2012, 134, 8646-8654. [CrossRef] [PubMed]

63. Ghaemi, M.; Biglari, Z.; Binder, L. Effect of Bath Temperature on Electrochemical Properties of the Anodically Deposited Manganese Dioxide. J. Power Sources 2001, 102, 29-34. [CrossRef]

64. Jacob, G.M.; Zhitomirsky, I. Microstructure and Properties of Manganese Dioxide Films Prepared by Electrodeposition. Appl. Surf. Sci. 2008, 254, 6671-6676. [CrossRef]

65. Johns, P.; Roberts, M.; Owen, J. Conformal Electrodeposition of Manganese Dioxide onto Reticulated Vitreous Carbon for 3D Microbattery Applications. J. Mater. Chem. 2011, 21, 10153-10159. [CrossRef]

66. Gibson, A.J.; Burns, R.C.; Dupont, M.F.; Donne, S.W. Mesoscale Morphological Control of Electrodeposited Manganese Dioxide Films. Electrochim. Acta 2015, 170, 343-352. [CrossRef]

67. Simon, P.; Gogotsi, Y. Materials for Electrochemical Capacitors. Nat. Mater 2008, 7, 845-854. [CrossRef] [PubMed]

68. Ghodbane, O.; Pascal, J.L.; Favier, F. Microstructural Effects on Charge-Storage Properties in $\mathrm{MnO}_{2}$-Based Electrochemical Supercapacitors. ACS Appl. Mater. Interfaces 2009, 1, 1130-1139. [CrossRef] [PubMed]

69. Augustyn, V.; Simon, P.; Dunn, B. Pseudocapacitive Oxide Materials for High-Rate Electrochemical Energy Storage. Energy Environ. Sci. 2014, 7, 1597-1614. [CrossRef]

70. Sarciaux, S.; la Salle, A.L.G.; Verbaere, A.; Piffard, Y.; Guyomard, D. $\gamma-\mathrm{MnO}_{2}$ for Li Batteries: Part I. $\gamma-\mathrm{MnO}_{2}$ : Relationships between Synthesis Conditions, Material Characteristics and Performances in Lithium Batteries. J. Power Sources 1999, 81-82, 656-660. [CrossRef]

71. Sarciaux, S.; la Salle, A.L.G.; Verbaere, A.; Piffard, Y.; Guyomard, D. $\gamma-\mathrm{MnO}_{2}$ for Li Batteries Part II. Some Aspects of the Lithium Insertion Process into $\gamma-\mathrm{MnO}_{2}$ and Electrochemically Lithiated $\gamma-\mathrm{Li}_{x} \mathrm{MnO}_{2}$ Compounds. J. Power Sources 1999, 81-82, 661-665. [CrossRef]

72. Hausbrand, R.; Cherkashinin, G.; Ehrenberg, H.; Gröting, M.; Albe, K.; Hess, C.; Jaegermann, W. Fundamental Degradation Mechanisms of Layered Oxide Li-Ion Battery Cathode Materials: Methodology, Insights and Novel Approaches. Mater. Sci. Eng. B Solid-State Mater. Adv. Technol. 2015, 192, 3-25. [CrossRef]

73. Jiang, F.; Peng, P. Elucidating the Performance Limitations of Lithium-Ion Batteries due to Species and Charge Transport through Five Characteristic Parameters. Sci. Rep. 2016, 6, 32639. [CrossRef] [PubMed]

74. Dose, W.M.; Donne, S.W. Optimizing Li/ $\mathrm{MnO}_{2}$ Batteries: Relating Manganese Dioxide Properties and Electrochemical Performance. J. Power Sources 2013, 221, 261-265. [CrossRef]

75. Bélanger, D.; Brousse, T.; Long, J.W. Manganese Oxides: Battery Materials Make the Leap to Electrochemical Capacitors. Electrochem. Soc. Interface 2008, 17, 49-52.

76. Minakshi, M.; Mitchell, D.R.G.; Prince, K. Incorporation of $\mathrm{TiB}_{2}$ Additive into $\mathrm{MnO}_{2}$ Cathode and Its Influence on Rechargeability in an Aqueous Battery System. Solid State Ionics 2008, 179, 355-361. [CrossRef]

77. Dose, W.M.; Donne, S.W. Optimising Heat Treatment Environment and Atmosphere of Electrolytic Manganese Dioxide for Primary Li/ $\mathrm{MnO}_{2}$ Batteries. J. Power Sources 2014, 247, 852-857. [CrossRef]

(C) 2017 by the authors. Licensee MDPI, Basel, Switzerland. This article is an open access article distributed under the terms and conditions of the Creative Commons Attribution (CC BY) license (http:/ / creativecommons.org/licenses/by/4.0/). 